\title{
Human Milk and Breast Feeding: an Update on the State of the Art
}

\author{
PEARAY L. OGRA ${ }^{(113,115)}$ AND HARRY L. GREENE ${ }^{(114)}$ \\ Councils of the Society for Pediatric Research and the American Pediatric Society
}

\begin{abstract}
The human neonate and its mammalian counterparts have for millions of years received balanced nutrition during early infancy exclusively through breast feeding. It is safe to assume that maternal milk has represented the sole source of infant feeding until a few thousand years ago when man learned to domesticate cattle, and nonhuman milk became available to supplement or replace traditional nursing. One can only speculate about the possible reasons underlying the introduction of nonhuman milk as a substitute source of nutrition in early infancy in ancient civilizations. Such alternate feeding practices, although uncommon, may have been related to the spontaneous cessation of the lactational process, maternal disease or death, insufficient milk syndrome, and early discontinuation of breast feeding of one infant to make room for a newly arrived sibling. These possibilities are supported by the existing practices of infant feeding, especially in technologically underprivileged countries, where the traditional approach to infant nutrition has been significantly altered by such factors $(1,2)$.
\end{abstract}

In addition, modern day societies are overwhelmed by other circumstances that adversely affect the extent of maternal-neonatal interactions as well as the process of breast feeding. These include, rapid urbanization, overpopulation and environmental pollution, increased participation of women in the industrial work force, changing concepts of family units, and an imbalance between the availability of a wide variety of infant formula and the financial inability to afford their prolonged use in many underprivileged socio-economic settings. The existing prevalence of acute mucosal viral and bacterial infections, especially infantile diarrhea and acute respiratory infections, and malnutrition often associated with high mortality and morbidity appear to be the result of the interplay among the complex set of problems identified above (3, 4). However, sufficient scientific data do not exist at this time to dissect out the relative role of each of these factors in the decline of breast feeding practices in many parts of the world, and in the prevailing patterns of diarrheal disease and malnutrition.

The current debate over the relative merits of breast versus formula feeding is not new. It dates back over three decades when it was first demonstrated that feeding of cow's milk formula to low birth weight infants provided higher protein intakes and resulted in better weight gain than observed with human milk (57). Although a final resolution of this debate seems unlikely in the immediate future, sufficient information has become available during the past decade to provide a more scientific perspective of the nutritional and other biologic aspects of human milk, and its potential role in the maturation of the human neonate.

The current approaches to infant feeding have been based, on the level of available knowledge of nutritional requirements of full term and low birth weight (LBW) infants, and on established cultural traditions in many contemporary societal settings. Existing information about infant nutrition and immunobiologic aspects of human milk, which may influence the choice of breast versus bottle feeding of infants in different parts of the world, is summarized.

\section{NUTRITIONAL AND OTHER REQUIREMENTS OF NEONATES}

The growth and development of an infant is a dynamic process. Although the requirements for normal growth are complex and poorly defined, a variety of intrinsic host factors and a multitude of nutritional and other environmental factors must contribute to the process. It is generally accepted that physical growth of the body and development of the central nervous system are determined by adequate intake of calories, protein and other essential nutrients. Practical guidelines based on available scientific data have been developed by the Committee on Nutrition of the American Academy of Pediatrics (8). It is doubtful that these guidelines are uniformally applicable in all parts of the world; however, they provide a framework of reference standards for minimal and maximal requirement for a variety of nutrients, and have been extremely helpful in evaluating nutritional needs of growing normal and LBW infants in the United States.

The average caloric requirement for a normal full term infant from the second day of age through the first year of life is estimated to be about $100-110 \mathrm{Kcal} / \mathrm{kg} /$ day. Caloric intake of less than $80 \mathrm{Kcal} / \mathrm{kg} /$ day is usually insufficient for physiologic needs, and intakes over $120 \mathrm{Kcal} / \mathrm{kg} /$ day may be associated with obesity (9). The minimum requirement for protein has been estimated to be about $1.8 \mathrm{~g} / 100 \mathrm{Kcal}$ and protein intake of over $4.5 \mathrm{~g} / 100 \mathrm{Kcal}$ may result in increased urea nitrogen retention. It has been recommended that fats constitute $30 \%$ to $54 \%$ of caloric intake. Although no specific requirements for fats has been demonstrated, a minimum of $3.38 \mathrm{~g} / 100 \mathrm{Kcal}$ and a maximum of $6.0 \mathrm{~g} / 100 \mathrm{Kcal}$ have been proposed as reasonable limits. Recommendation has been made to provide $3 \%$ of total calories (or $300 \mathrm{mg} / 100 \mathrm{Kcal}$ ) as linoleic acid. Adequate amounts of readily digestible carbohydrates are needed to maintain normal blood glucose levels and to prevent ketoacidosis. Calcium and phosphorus are required in larger amounts during early infancy. In addition, specific recommendations have been made for the minimal intake of fat soluble vitamins ( $\mathrm{A}, \mathrm{D}, \mathrm{E}, \mathrm{K})$; water soluble vitamins (ascorbic acid, thiamine, riboflavin, pyridoxine, vitamin $B_{12}$, niacin, folic acid, biotin, choline, inositol); minerals (manganese, zinc, iron, copper, magnesium, iodine); and the major electrolytes such as sodium, potassium and chloride (10).

The nutritional requirements of premature and LBW infants have not been clearly established; however, hypothetical models of postnatal weight gain, in which it is assumed that the chemical composition of a growing LBW infant and its rate of weight gain should be similar to that of a normal fetus of a similar weight, have provided valuable insight into the potential nutritional needs of $\mathrm{LBW}$ infants $(11,12)$. The nutritional needs of a $\mathrm{LBW}$ infant appear to be significantly higher than the requirements of a normal full term infant. Based on the requirement of a normal neonate, it has been estimated that the daily requirements of a growing LBW infant of $1200 \mathrm{~g}$ are approximately $144 \mathrm{Kcal}$ of calories, $2.54 \mathrm{~g} / 100 \mathrm{Kcal}$ of protein, $132 \mathrm{mg} / 100 \mathrm{Kcal}$ of calcium and $2.3 \mathrm{mg} / 100 \mathrm{Kcal}$ of sodium (13). On the other hand, there are 
certain environmental conditions that may influence these requirements. For example, it is known that substantial positive nitrogen balance can be achieved with $80 \mathrm{Kcal}$ of calories in a thermoneutral environment (14).

Although environmental factors and intact mechanisms of defense are important in the long term growth and developmental process, little or no information is available regarding the quantitative requirements of such ingredients as antimicrobial defense, specific immunocompetence and the level of maternal-neonatal emotional interaction, for optimum growth and development.

\section{COMPOSITION OF HUMAN MILK}

Nutritional components. The chemical composition of human milk exhibits considerable variation between different individuals and in the same individual at different times of lactation (15), as well as between samples obtained from mothers of LBW infants and full term infants $(16,17)$. Mature human milk contains the following average amounts of the various chemical constituents per $100 \mathrm{ml}$ : total solids, $11.3 \mathrm{~g}$, fat, $3.0 \mathrm{~g}$; protein, $0.9 \mathrm{~g}$; whey protein nitrogen, $76 \mathrm{mg}$; casein nitrogen, $41 \mathrm{mg} ; \alpha$-lactalbumin, $150 \mathrm{mg}$; serum albumin, $50 \mathrm{mg}$; lactose, $7.2 \mathrm{~g}$; lactoferrin, $150 \mathrm{mg}$; lysozyme, $50 \mathrm{mg}$; sodium, $15 \mathrm{mg}$; potassium, $55 \mathrm{mg}$; calcium, 43 $\mathrm{mg}$; vitamin C, $4.3 \mathrm{mg}$; and retinol, $54 \mu \mathrm{g}(9)(18,19)$. Human milk contains little or no $\beta$-lactoglobulin. The fat globule membrane of human milk appears to have a high content of oleic acid, linoleic acid, phosphatidopeptides and inositol (20). In addition, a zinc binding ligand, which promotes absorption of zinc, has been identified in the human milk $(21,22)$. Human milk is considered to be deficient in vitamin D (9). Temporal studies of human milk have indicated that the concentration of many chemical components, especially nitrogen, calcium, and sodium decrease significantly as the duration of lactation increases $(9,10)$; however, several components have been found to change in concentration as a function of water content, because their total daily output appears to be remarkably constant at least during the first 8 wk of lactation $(23,24)$.

Host resistance factors. Fresh human milk contains a wealth of components that provide specific as well as nonspecific defenses against infectious agents or other macromolecules $(25,26)$. These include immunocompetent $\mathrm{T}$ and $\mathrm{B}$ lymphocytes, polymorphonuclear leukocytes, macrophages (27-29), immunoglobulins, especially secretory $\operatorname{IgA}(29,30)$, and components of complement system $(25,31,32)$. Additional soluble factors which are active against streptococci, staphylococci and tumor viruses (33-35) have also been identified. Of these components, the developmental characteristics of secretory $\operatorname{IgA}$ in the human colostrum and milk have been studied most extensively. Based on the available information, it is reasonably certain that $\operatorname{IgA}$ producing plasma cells observed in the milk derive their origin from the precursor immunocompetent cells in the gut-associated (GALT) and bronchialassociated lymphoid tissue (BALT). It is believed that exposure of IgA precursor B lymphocytes in GALT or BALT to microbial and dietary antigen in the mucosal lumen is an important prerequisite for their initial activation and proliferation. Such antigen-sensitized cells are eventually transported via the systemic circulation to other mucosal surfaces, including the mammary glands, and initiate as plasma cells synthesis of immunoglobulin against specific antigens previously experienced in the mucosa of respiratory or alimentary tracts $(30,36,37)$. It has been proposed that the $\mathrm{T}$ cell reactivity observed in the milk may also be derived from GALT and BALT, in a manner similar to the appearance of IgA producing cells (29). Little or no information is available regarding the site or origin of other cellular or soluble immunologic components normally present in human milk. Specific antibody and cellular immune reactivity against many bacteria, viruses, respiratory and enteric pathogenic organisms (hemophilus influenzae, salmonella, shigella, rotavirus), fungi, parasites, and ingested food proteins have been repeatedly demonstrated in the human breast milk (27-30). Other soluble milk factors with potential implica- tions in host defense include bifidus factor, which promote growth of bifidobacteria (20), and an epidermal growth factor $(38,39)$, which promotes growth of mucosal epithelium and maturation of intestinal brush border enzymes.

Infectious organisms. Samples of human milk obtained from recently infected or vaccinated lactating mothers have been found to contain appreciable number of infectious microorganisms (29). Recovery of rubella virus (40), cytomegalovirus $(41,42)$, hepatitis B surface antigen (43), mycobacteria tuberculosis, pathogenic staphylococcus, streptococci and enteric pathogens (44) have been demonstrated on several occasions in freshly collected human milk.

Other chemical components. To date, little information has been accumulated regarding the presence and significance of environmental pollutants, toxins, chemicals and therapeutically administered drugs in the human milk (45); however, a number of chemical contaminants have been observed in the breast milk. These include organohalides (polychlorinated biphenyls-PCB, and dichlorodiphenyl trichloroethane-DDT) and a number of other chlorinated pesticides (46), drugs and antibiotics $(47,48)$, caffein (49), nicotine (50), lead (51) and radiopharmaceuticals (52, 53). In general, the environmental contaminants observed in breast milk have high lipid solubility, resist physical degradation and biologic metabolic activity, and are slow in their rates of excretion from the human body (46). Many environmental chemicals are present in breast milk in concentrated amounts as a result of well known bioconcentration phenomena (46).

\section{COMPARISON OF HUMAN MILK WITH COW'S MILK AND PREPARED} FORMULA PRODUCTS

Cow's milk. The chemical composition of cow's milk, which has been a standard food for infant nutrition for many years, differs in a number of ways from human milk. The concentrations of protein, whey protein nitrogen, sodium and potassium in cow's milk are two to three times higher than in human milk. Cow's milk contains larger quantities of $\beta$-lactoglobulin, methionine and phenylalanine, and adequate amounts of vitamin A, B vitamins and vitamin $\mathrm{K}$. Cow's milk is usually fortified with vitamin D before human use. Evaporated cow's milk fails to meet the minimum requirements of vitamin $\mathrm{C}$, vitamin $\mathrm{E}$, and essential fatty acids (54). The concentrations of carbohydrate, lactose, $\beta$-lactalbumin, lysozyme, cysteine, taurine, and secretory $\operatorname{IgA}$ in cow's milk are significantly lower than in the human milk (20). Despite the reduced level of secretory IgA, cow's milk contains large quantities of IgG, which appears to function as a source of secretory antibody for the calf in a manner similar to $\operatorname{IgA}$ in the human infant (36). Although complement activity has been observed in the cow's milk (55), little or no information is available regarding the amount and function of other soluble or cellular mechanisms of host defense. A number of pathogenic microorganisms have been observed in fresh bovine milk. These include salmonella (56), campylobacter fetus (57), and yersinia enterocolitica (58). In addition, anecdotal observations have also reported the presence of other organisms in bovine milk. It is believed that cow's milk contains more excreted tissue metabolites than human milk (20). Only limited information is available about the spectrum of environmental chemical and toxins present in cow's milk.

Milk formula. It is beyond the scope of this review to discuss details of the numerous commercially available milk formulas, although certain general aspects will be mentioned. First, the nutrient content is standardized, and by measuring the amount an infant consumes, the energy-protein intake can be accurately calculated. Second, the most frequently used formulas are prepared from nonfat cow's milk, vegetable oils and added carbohydrate-usually lactose but occasionally corn syrup solids. Third, the formulas are supplemented as necessary to meet or exceed the recommended intake of vitamin and minerals, and are generally available in the form of a powder, concentrated liquid or readyto-feed liquid. Fourth, most products contain a casein protein to whey protein ratio of $82: 18 \%$ although some of the "humanized" 
milks have a casein protein to whey protein ratio of $60: 40 \%$, similar to human milk (10).

In addition to the more standard milk formulas, a number of modified formulas designed for infants with special needs have been made available. These formulas are usually lactose-free, with glucose polymers as a carbohydrate source. Other formulas may have a portion of the long chain fatty acids replaced by medium chain fatty acids; and still other formulas may have nitrogen source consisting of hydrolyzed protein, or in some instances crystalline amino acids. These formulas have been extremely advantageous in increasing the absorptive potential of infants with bowel disease, or normalize blood glucose and amino acid levels in patients with inborn errors of metabolism (59).

\section{BENEFICIAL EFFECTS OF BREAST FEEDING}

Nutritional benefits. The composition of human milk meets the minimum requirements for protein and calories for a growing full term infant, despite the fact that protein content of pooled human milk is low $(0.9 \mathrm{~g} / \mathrm{ml})$. Breast feeding seems to result in a more balanced solute load because breast fed babies appear to require less water than babies fed on cow's milk. Human milk contains far less amounts of nonhuman proteins (bovine serum proteins and $\alpha$-lactoglobulin) than observed in the milk of domestic animals. Due to the quantitative differences in the content of protein between human milk and milks from other mammalian species, the relative amount of aminoacids is also different. Human milk contains greater amounts of cholesterol, and cysteine and taurine amino acids thought to be important for growing neonates and infants (60). On the other hand, the amounts of methionine and phenylalanine, which are poorly tolerated by some infants, are found in lower concentrations in human milk $(20,60)$. It has been suggested that the fat absorption of infants on human milk may be greater than in infant's fed cow's milk or artificial formulas, with the possible exception of infants fed formula products containing medium chain triglycerides $(61,62)$; however, this does not appear to be a significant argument in favor of breast milk, in view of the fact that fat preparations used in most currently available formula products are well absorped. Breast feeding has also been suggested to confer some nutritional advantages in later life. Limited and somewhat circumstantial observations suggest that breast fed infants may develop more effective mechanisms for cholestrol handling in later life and may tend to be less obese as adults (63-65). However, more recent studies have not confirmed these observations.

Commercial formula products frequently require reconstitution and supplementation with certain additives during manufacture or at the time of its feeding to the infant. Unless carefully controlled, such manipulations can result in accidental imbalance of certain constituent components in the infant formula. Recently, at least two formula products were found to contain levels of sodium and chloride below the standards recommended by the Committee on Nutrition of the American Academy of Pediatrics (8). Such imbalances in infant formula products although very rare, have however, been associated with limited morbidity in some infants in the United States $(66,67)$. The accidental use of such imbalanced formula products, in the face of inadequate regulatory mechanisms for quality control, may result in potential problems in developing countries where such infants may not be brought to medical attention promptly and the feeding may even be continued for long periods.

Role of defense factors. Careful, albeit sparse epidemilogic studies conducted recently in several rural and urban settings have demonstrated a striking resistance of breast fed infants to colonization by coliform organisms especially enteropathogenic Escherichia coli, shigella, Vibrio cholera and protozoa, even under field conditions when the risk of natural infection is high $(3,20,68$ 71). It is however, not known whether such protection is mediated by microbial specific immunologic components or nonspecific defense factors present in the milk. It has also been proposed that as a result of the proliferation of bifidobacteria exclusively in the intestine of breast fed infants and the subsequent accumulation of short chain fatty acids and other bacterial metabolites, the intestinal milieu in such infants may be antagonistic to the replication of other invasive enteric pathogens $(69,72)$. Frequently, infant formula products require reconstitution in water before its ingestion by the infant. Because of poor sanitary conditions in many developing countries, such reconstitution introduces potential risk of pathogenic microbial contamination in the infant feeds. On the other hand, breast feeding is not subject to latrogenic contamination by such pathogenic organisms, often endemic in the drinking water in many underdeveloped nations.

Breast milk has also been shown to prevent the development of hypoxia-infection induced necrotizing enterocolitis in a rat model (73), but controversial data exist on the role of breast feeding in the human form of the disease $(74,75)$. The information about the protective role of breast feeding in neonatal sepsis, acute respiratory infections, and intestinal viral infections is conflicting, or presumptive at best $(71,76-79)$.

Other beneficial aspects. Ingestion of early colostrum in beagle puppies has been shown to have profound influence on the maturation of intestinal brush border enzymes and growth of intestinal mucosal epithelium in the neonatal period (39). This activity appears to be related to the presence of epidermal growth factor (EGF). It has been identified in the human breast milk (14) and appears to stimulate fibroblast proliferation in vitro (80). A few clinical studies have suggested that breast feeding may decrease the frequency of eczema or other allergic reactions and improve the long term prognosis of childhood asthma $(37,81)$.

Recent observations have raised the possibility that the active process of breast feeding favors maternal-neonatal emotional "bonding," and thus foster strong social interactions between the child and the parent at later stages of the child's life $(82,83)$. Such interactions may have a positive impact on cultural endowment of the child in traditional societies.

In modern day society perhaps, the single most important consideration for the use of breast feeding is its cost. An analysis of the cost effectiveness of the available modalities of infant nutrition carried out recently has concluded that "breast feeding is the cheapest means of feeding a child during the first six months of life" $(84,85)$. It has been estimated that the cost of artificial feeding of an infant is far more than it would require to provide sufficient caloric intake to the lactating mother to secrete adequate amounts of milk (86). It is particularly important to note that the monthly cost of breast feeding in Costa Rica has been estimated to be about $5 \%$ of the minimum wage compared to about $18 \%$ of the minimum wage for the cost of feeding formula (20). The cost of infant feeding by artificial means in other underprivileged countries of Africa and Asia may be even higher. Such an expense makes routine use of formula feeding obviously unrealistic in these countries.

\section{LIMITATIONS OF BREAST FEEDING}

Nutritional limitations. Term infants: Although breast feeding provides recommended levels of nutrition to a normal neonate, there seems to be little doubt that infants fed human milk do not grow as rapidly as those fed most commercial formulas $(5,6,87-$ 89). There is, however, no evidence to suggest that rapid growth is a desirable goal of nutrition for normal neonates. Nutritional deficits, including deficiency of pyridoxine, thiamine, vitamin $B_{12}$ and vitamin $D$ in certain population of breast fed infants is also well known (90-92).

Low birth weight infants: As discussed earlier, the nutritional requirments of $\mathrm{LBW}$ infants are quite different from those of the term infants. Specific studies in low birth weight infants have shown that formula with a high energy-protein density promotes more rapid growth than observed with feeding of human milk (93). From these studies and other reference models of body analysis, some authors have concluded that pooled human milk, when fed in the usual amounts, does not provide sufficient amounts of protein, calories, minerals and solutes to allow accretion of these nutritional elements at the intrauterine rate when 
nutritional requirements are considered for a $\operatorname{LBW}$ infant $(13,94)$. As a result, several proprietary formulas have been designed to meet the projected needs of this unique infant population. Recent data from analysis of milk from mothers delivering prematurely suggest that the use of LBW infant's own mothers milk may provide gross and metabolisable energy intakes similar to the infant's calculated needs (95). In addition, feeding of such milk in LBW infants appears to result in plasma protein and albumin concentrations, and weight gain during the first 2 wk of life similar to those observed after feeding of an infant formula (95).

Breast feeding failures. Insufficient milk syndrome and breast feeding-failure is a common experience in all parts of the world, particularly in primiparous women (96-98). It has been estimated that at least $20 \%$ of primiparous women may have complete failure of breast feeding and up to $50 \%$ of lactating women may exhibit significant nursing difficulties (99). Recently, critical malnutrition characterized by hypothermia, azotemia, and severe dehydration has been observed in a few full term otherwise normal first-born infants nourished solely through breast feeding (100).

Transmission of infectious organisms. Several recent reports have indicated that microorganisms excreted in the breast milk of infected or vaccinated mothers can result in the development of serologic evidence of specific infection in the neonate, possibly via the process of breast feeding $(29,42,101,102)$. Such acquisition of immunologic reactivity is often associated with recovery of the infectious agent in the mucosal surfaces of the neonate $(101,102)$. Despite these observations, acquisition of clinical disease in the suckling infant has not been clearly documented (101-103).

Transmission of chemical contaminants. The role of milk contaminants in production of disease in breast feeding infants has not been carefully studied to date, and as a result it is difficult to assess their risk for the neonate. A single case of neonatal obstructive jaundice due to chlorinated hydrocarbon in the milk has been reported (104); however, it is encouraging to note that no other cases of defined illnesses due to breast milk contaminants have been reported in the suckling neonates and infants. It is also not known whether environmental chemicals or drugs alter the immunologic defense mechanisms in the human milk.

\section{OVERVIEW OF THE STATE OF THE ART}

It is clear on historical grounds alone that breast feeding has served mankind well in promoting the survival of the neonates through the ages. Based on the recently acquired knowledge concerning the content and functional role of nutritional, biochemical, microbial and immunologic components in human milk, the adequacy of breast feeding in promoting growth and development of a normal infant is well established. There are, however, a few exceptions. Deficiencies of pyridoxine, thiamine, and vitamin $B_{12}$ have been observed in breast fed infants whose mothers consumed insufficient amounts during lactation (105-107). The development of vitamin $\mathrm{D}$ deficiency has been observed exclusively in breast fed infants (108), although it has been seen more frequently in infants in whom exposure to sunlight is restricted by cultural or climatic conditions. Breast feeding failures and insufficient milk syndrome have been frequently observed in primaparous women. Infant malnutrition as a result of such inadequacy of milk supply, although rare, has also been reported in the first born infants. Evidence has been presented to indicate that the caloric content, and the concentrations of protein, calcium, and sodium in human milk are inadequate for the optimal estimated growth of LBW infants. Many of these calculations are based on growth requirements of very small premature infants, particularly those weighing 1100 to $1800 \mathrm{~g}$ at birth. The inadequacy of breast milk for LBW infants is accentuated if nutritional requirements are calculated on the basis of weight gain of $30.7 \mathrm{~g} /$ day (13). However, in bigger premature infants in whom the calculations for weight gain are restricted to $20 \mathrm{~g} / \mathrm{day}$, the feeding of human milk has been estimated to meet the recommended nutritional requirements for protein and sodium, but not for calcium (13). Clearly, the nutritional comparisons of human milk and formula feeds become extremely complex when viewed in the context of ideal growth requirements and metabolic costs of normal versus LBW infants, and biologic value of human versus nonhuman milk for nutritional support of human infants. Formula feeds appear to offer the advantage of enhanced growth and weight gain for a LBW infant; however, cow's milk, although having higher protein and a higher caloric load, may not provide sufficient amounts of all aminoacids required by the LBW infant. Such feeding may also promote fluid and electrolyte imbalance (20). One of the major difficulties in meaningful comparisons of nutritional value of human and nonhuman milks is related to the fact that precise requirements for the ideal growth and developmental profile of a normal or LBW infant are not known at this time, and until such information becomes available, it is difficult to foresee a resolution of this argument.

Although not a limitation of human milk per se, it must be realized that with increasing frequency, many mothers may not be able to sustain lactation, produce milk in sufficient amounts, and breast feed at optimal frequencies for a variety of physical or societal reasons (95-98). In addition, the increased survival of many high risk LBW infants have created unique nutritional demands, which often have to be tailored to the caloric requirements of individual infants. Availability of highly specialized formula products in recent years has been of immense value in providing nutritional support to infants with inborn or acquired errors of metabolism and with other disease states that preclude the use of human milk (10).

It has been suggested that breast feeding may provide protection against the development of allergic disease; however, data on which such belief is based are highly presumptive, and other laboratory studies have suggested that IgE levels and specific reagenic antibody activity against egg proteins and bovine milk proteins may be even higher in breast fed allergic infants than in nonbreast fed infants $(109,110)$.

Recent epidemiologic studies in several tropical countries have provided strong evidence for a protective role for breast feeding especially against enteric infections. On the other hand, little information is available to support a beneficial role of breast feeding against respiratory infection and neontal sepsis. In fact, a few clinical case reports have raised the possibility that ingestion of human milk contaminated with group B beta hemolytic streptococcus may be associated with development of clinical disease in the neonate $(111,112)$. These observations need to be confirmed and much needs to be learned about the anti-infective aspects of human milk and breast feeding in additional controlled studies. Somewhat stronger evidence is presented in other scattered cases for the development of salmonellosis, brucellosis, campylobacter fetus and yersinia enteritis, in the human infants after ingestion of contaminated raw nonhuman milk. Therefore, the potential for transmission of disease-producing pathogens via fresh human milk should not be overlooked especially in situations of actively infected lactating mothers nursing susceptible neonates and in the distribution of milk products from milk banks.

It is evident that a number of environmental pollutants and chemotherapeutic agents are excreted in the milk. Their potential role in the production of disease and their pharmacologic implications in breast feeding infants remain to be determined.

As a result of continued physical contact between the mother and suckling infant, the psychologic impact of breast feeding is believed to be profound; however, specific prospective data are not available at this time to clearly delineate its role in the long term emotional development and social adaptability of the breast fed child in later life.

The cost effectiveness of breast feeding for normal term infants is obviously superior to that of formula feeding. The available experience with breast feeding in providing adequate nutritional support for millions of normal infants born in families with very sparse financial resources, represents a strong argument in support of breast feeding, especially in the many economically underprivileged countries of the world.

Despite the wealth of available scientific data, significant gaps 
remain in the existing knowledge concerning infant nutrition, infection-malnutrition axis and immunobiologic aspects of human milk. Although breast milk is uniquely designed for the human infant, conclusive evidence of overwhelming nutritional advantages of human milk and breast feeding over commercial milk products (which are properly reconstituted under sterile conditions) is not available at this time.

The regulation of marketing practices for the use of breast milk substitutes, and adoption of measures designed to promote breast feeding, may to be appropriate albeit, transitional measures to combat infant malnutrition. It is apparent that a massive global effort must be mounted to seek more specific and viable solutions for the complex basic problems underlying the nutritional deprivation in millions of infants and children all over the world.

In view of its universal availability, lack of any manufacturing costs, absence of overt nutritional limitations for normal infants, and the abundant content of many host-defense factors, it is recommended that human milk and breast feeding should continue to remain the cornerstone of nutrition in early infancy, at least, until the complex mechanisms of global malnutrition are better defined. Promotion of breast feeding should constitute a major goal of the professionals involved in maternal and child health care, especially in low socioeconomic settings and in underprivileged countries. At the same time, it must be emphasized that the commercial formula products have served as valuable nutritional supplements, and in certain situations, as effective replacement to human milk when breast feeding is not available, inadequate or difficult to implement. As a result, the importance of commercial formula products for infant nutrition must not be ignored as efforts are made to encourage reinstitution of breast feeding in different parts of the world.

\section{REFERENCES AND NOTES}

1. Chavez, A., Martinez, C., Bourges, H., et al.: Child nutrition problems during lactation in poor rural areas. In: Nutrition, Chavez, A., Bourges, H. and Basta, S. (Eds) p 90. (Karger, Basel, 1975).

2. Solien de Gonzalez, N. L.: Breast-feeding, weaning and acculturation. J. Pediatr. 62: 577 (1963).

3. Mata, L. J., Kronmal, R. A., Garcia, B., et al.: Breast-feeding, weaning and the diarrhoeal syndrome in a Guatemalan Indian village. In: Acute Diarrhoea in Childhood. Ciba Found. Symp. No. 42 p 311. (Elsevier/Excerpta Medica, Amsterdam, 1976)

4. Mata, L. J.: The Children of Santa Maria Cauque: a Prospective Field Study of Health and Growth p. 254. (The MIT Press, Cambridge, MA., 1978).

5. Powers, G. F.: Some observations on the feeding of premature infants based on 20 years experience at the New Haven Hospital. Pediatrics, 1: 145 (1948).

6. Gordon, H. H., Levine, S. Z., and McNamara, H.: Feeding of premature infants: a comparison of human and cow's milk. Am. J. Dis Child., 73: 442 (1947).

7. Kagan, B. M., Hess, J. H., Lundeen, E., et al: Feeding of premature infants: a comparison of various milks. Pediatrics, 15: 373 (1955).

8. Commentary of breast-feeding and infant formulas, including proposed standards for formulas, Committee on Nutrition, American Academy of Pediatrics. Pediatrics, 57: 278 (1976)

9. Fomon, S. J..: Infant Nutrition (2nd ed), W. B. Saunders, Philadelphia, 1974.

10. Woodruff, C. W.: The science of infant nutrition and the art of infant feeding. JAMA, 240: 657 (1978)

11. O'Donnell, A. M., Ziegler, E. E., and Fomon, S. J.: Ingestas recomendadas de nutrientes para prematuros en crecimiento. Arch. Argent. Pediatr., 72: 126 (1974).

12. Ziegler, E. E., O'Donnell, A. M., Nelson, S. E., et al.: Body composition of the reference fetus. Growth, 40: 329 (1976).

13. Foman, S. J., Ziegler, E. E., and Vazquez, H. D.: Human milk and the small premature infant. Amer. J. Dis. Child., 131: 463 (1977).

14. Anderson, T. L., Muttart, C. R., Bieber, M. A., et al.: A controlled trial of glucose versus glucose and aminoacids in premature infants. J. Pediatr, 94: 947 (1979).

15. Lonnerdale, B., Forsum, E., and Hambraeus, L.: The protein content of human milk. I. A transversal study of Swedish normal mothers. Nutr. Rep. Int., 13: 125 (1976).

16. Schanler, R. J. and Oh, W.: Composition of breast milk obtained from mothers of premature infants as compared to breast milk obtained from donors. $\mathbf{J}$. Pediatr., 96: 679 (1980).

17. Sann, L., Bienvenu, F., Lahet, C., et al.: Comparison of the composition of breast milk flrom mothers of term and preterm infants. Acta Paediatr. Scand. 70: 115 (1981)

18. Lonnerdal, B., Forsum, E., and Hambraeus, L.: A longitudinal study of the protein, nitrogen, and lactose contents of human milk from well nourished Swedish mothers. Am. J. Clin. Nutr., 29: 1127 (1976).

19. Lonnerdal, B., Forsum, E., Gebre-Medhin, M., et al.: Breast milk composition in Ethiopan and Swedish mothers. II. Lactose, nitrogen and protein contents. Amer. J. Clin. Nutr., 29: 1134 (1976).

20. Mata, L.: Breast-feeding: main promoter of infant health. Amer. J. Clin. Nutr., 31: 2058 (1978).

21. Hurley, L. S., Lonnerdal, B., and Stanislowski, A. Q.: Zinc citrate, human milk and acrodermatitis enteropathica. Lancet, 1: 677 (1979).

22. Eckhert, C. D., Sloan, M. V., Duncan, J. R., et al.: Zinc binding: a difference between human and bovine milk. Science, 195: 790 (1977).

23. Moran, R., Vaughn, R., Mount, C., et al.: Epidermal growth factor concentrations and daily production in breast milk during seven weeks post delivery in mother of premature infants. Pediatr. Res., 16: (Abstract), (1982).

24. Moran, R., Borum, P., Vaughn, R., et al.: The concentrations and daily output of trace elements, vitamins and carnitine in breast milk from mothers of premature infants for seven postnatal weeks. Pediatr. Res. Abstract, 16: (1982).

25. Goldman, A. S. and Smith, C. W.: Host resistance factors in human milk. J. Pediatr., 82: 1082 (1973).

26. Hanson, L. A., and Johansson, B. G.: Immunological studies of milk. In Milk Proteins, Vol. 1, pp 45-123 (Academic Press, New York, 1970).

27. Ogra, S. S. and Ogra, P. L.: Immunologic aspects of human colostrum and milk. I. Distribution characteristics and concentrations of immunoglobulins at different times after the onset of lactation. J. Pediatr., 92: 546 (1978)

28. Ogra, S. S. and Ogra, P. L. Immunologic aspects of human colostrum and milk. II. Characteristics of lymphocyte reactivity and distribution of E-rosette forming cells at different times after the onset of lactation. J. Pediatr. 92: 550 (1978)

29. Ogra, P. L. and Dayton, D. H. (Eds), Immunology of Breast Milk, (Raven Press, New York, 1980).

30. Goldblum, R. M., Attlstedt, S., Carlsson, B., et al.: Antibody forming cells in human colostrum. Nature, 257: 797 (1976).

31. McClelland, D. B. L., McGrath, J., and Samson, R. R.: Antimicrobial factors in human milk. Acta Paediatr. Suppl. 271:1-20, 1978.

32. Chandra, R. K.: Immunological aspects of human milk. Nutr. Rev. 36: 265 (1978).

33. Oram, J. D. and Reiter, B.: The inhibition of streptococci by lactoperoxidase, thiocyanate and hydrogen peroxide. The effect of the inhibitory system on susceptible and resistant strains of group streptococci. Biochem. J., 100: 373 (1966)

34. Gyorgy, P.: Human milk and resistance to infection. In: Nutrition and Infection. Ciba Found. Study Group no. 31 p 59 (Little, Brown and Co., Boston, 1967) p. 59.

35. Ribonuclease as antiviral agent in milk. Lancet, $1: 431$ (1977).

36. Ogra, P. L.: Ontogeny of the local immune system. Pediatrics (suppl), 64: 765 (1979).

37. Kleinman. R. E. and Walker, W. A.: The enteromammary immune system: An important new concept in breast milk host defense. Digest. Dis. Sci., 24: 876 (1979).

38. Carpenter, G.: Epidermal growth factor is a major growth promoting agent in human milk. Science, 210: 198 (1980).

39. Schwarz, S. M. and Heird, W. C.: Further studies of colostrum-stimulated enteric mucosal growth. Pediatr. Res. (Astract), 15: 546 (1981)

40. Buimovicci-Klein, E., Hite, R. L., Byrne, T., et al.: Isolation of rubella virus in milk after postpartum immunization. J. Pediatr., 91: 939 (1977).

41. Hayes, K., Danks, D. M., Gibas. H., et al.: Cytomegalovirus in human milk. New Engl. J. Med.. 287: 177 (1972).

42. Stagno, S., Reynolds, D. W., Pass, R. F., et al.: Breast milk and the risk of cytomegalovirus infection. New Engl. J. Med., 302: 1073 (1980).

43. Linneman, C. C., Jr., and Goldberg, S.: $\mathrm{HB}_{\mathrm{r}} \mathrm{Ag}$ in breast milk. Lancet 2: 155 (1974).

44. Ryder, R. W., Crosby-Ritchie, A., McDonough, B., et al.: Human milk contaminated with Salmonella kottbus. JAMA, 238: 1533 (1977).

45. Catz, C. S. and Giacoia, G. P.: Drugs and breast milk. Pediatr. Clin. N. Amer., 19: 151 (1972)

46. Rogan, W. J., Bagniewska, A., and Damstra, T.: Pollutants in breast milk. New Eng. J. Med., 302: 1450 (1980).

47. Kampmann, J. P., Johansen, K., Hansen, J. M., et al.: Propylthiouracil in human milk. Lancet $1: 736$ (1980).

48. Yoshioka, H., Cho., K., Takimoto, M., et al.: Transfer of cefazolin into human milk. J. Pediatr., 94: 151 (1979).

49. Tyrala, E. E. and Dodson, W. E.: Caffeine secretion into breast milk. Arch. Dis. Child., 54: 787 (1979).

50. Ferguson, B. B., Wilson, D. J., and Schaffner, W.: Determination of nicotine concentrations in human milk. Amer. J. Dis. Child., 130: 837 (1976).

51. Dillon, H. K., Wilson, D. J., and Schaffner, W.: Lead concentrations in human milk. Amer. J. Dis. Child., 128: 491 (1974).

52. Pittard, W. B., III, Bill, K., and Fletcher, B. D.: Excretion of technetium in human milk. J. Pediatr., 94: 605 (1979).

53. Weaver, J. C., Kamm, M. L., and Dobson, R. L.: Excretion of radio iodine in human milk. JAMA, 173: 872 (1960).

54. Woodruff, C. W., Bailey, M. C., David, J. T., et al.: Serum lipids in breast-fed infants and in infants fed evaporated milk. Amer. J. Clin. Nutr., 14: 83 (1964).

55. DeCueninck, B. J.: C142 complement activity and conglutinogen in bovine milk. Int. Archs. Allergy Appl. Immun., 59: 323 (1979).

56. Sharp, J. C. M., Paterson, G. M., and Forbes, G. I.: Milk-borne salmonelosis in Scotland. J. Infect., 2: 333 (1980)

57. Taylor, P. R., Weinstein, W. M., and Bryner, J. H.: Campylobacter fetus infection in human subjects: association with raw milk. Amer. J. Med., 66: 779 (1979).

58. Black, R. E., Jackson, R. J., Tsai, T., et al.: Epidemic Yersinia enterocolitica infection due to contaminated chocolate milk. New Eng. J. Med., 298: 76 
(1978).

59. Greene, H. L.: Nutritional support of the sick infant. Pediat. Ann., 10: 455 (1981).

60. Gaull, G. E., Rassin, D. K., Raiha, N. C., et al.: Milk protein quantity and quality in low birth weight infants. III. Effects on sulfur aminoacids in plasma and urine. J. Pediatr., 90: 348 (1977).

61. Roy, C. C., Ste.-Marie, M., Chartrand, L., et al.: Correction of the malabsorption of the preterm infant with a medium-chain triglyceride formula. J. Pediatr., 86: 446 (1975).

62. Andrew, B. F. and Lorch. V.: Improved fat and CA absorption in low birth weight infants fed a medium chain triglyceride containing formula. Pediatr. Res., 8: 378 (1974)

63. Foman, S. J. Filer, Jr, Thomas, $\mathrm{L}, \mathrm{N}$, et al: Growth and serum chemical values of normal breast fed infants. Acta Pediat. Scand. (suppl.), 202: (1970).

64. Hahn, P. and Koldovsky, O.: Utilization of nutrients during postnatal development. (Pergamon Press, New York, 1966).

65. Kramer, M. S.: Do breast feeding and delayed introduction of solid foods protect against subsequent obesity? J. Pediatr., 98: 883 (1981).

66. Linshaw, M. A., Harrison, H. L., Gruskin, A. B., et al.: Hypochloremic alkalosis in infants associated with soy protein formula. J. Pediatr. 96: 635 (1980).

67. Holliday, M. A.: Alkalosis in infancy and commercial formulas. Pediatrics, 65 : 639 (1980).

68. Wyatt, R. G., Garcia, B., Caceres, A., et al.: Immunoglobulins and antibodies in colostrum and milk of Guatemalan Mayan women. Arch. Latinoamer. Nutr., 22: 629 (1972).

69. Mata, L. J. and Urrutia, J. J.: Intestinal colonization of breast-fed children in a urural area of low socioeconomic level. Ann. N.Y. Acad. Sci., 176: 93 (1971).

70. Gunn, R.A., Kimball, A. M., Pollard, R. A., et al.: Bottle feeding as a risk factor for cholera in infants. Lancet, 2: 730 (1979).

71. Fallot, M. E., Boyd, J. L., III, and Oski, F. A.: Breast-feeding reduces incidence of hospital admissions for infection in infants. Pediatrics, 65: 1121 (1980).

72. Beerens, H., Romond, C., and Neut, C.: Influence of breast-feeding on the bifid flora of the newborn intestine. Amer. J. Clin. Nutr., 32: 2434 (1980).

73. Barlow, B., Santulli, T. V., Heird, W. C., et al.: An experimental study of acute neonatal enterocolitis-the importance of breast milk. J. Pediatr. Surg., 9: 587 (1974).

74. Santulli, T. V., Schullinger, J. N., Heird, W. C., et al.: Acute necrotizing enterocolitis in infancy: a review of 64 cases. Pediatrics, 55: 376 (1975).

75. Kliegman, R. M., Pittard, W. B., and Fanaroff, A. A.: Necrotizing enterocolitis in neonates fed human milk. J. Pediatr.. 95: 405 (1979).

76. Cunningham, A. S.: Morbidity in breast-fed and artificially fed infants. J. Pediatr., 90: 726 (1977).

77. Bishop, R. F., Cameron, D. J. S., Veenstra, A. A., et al.: Diarrhea and rotavirus infection associated with differing regimens for postnatal care of newborn babies. J. Clin. Microbiol., 9: 525 (1979)

78. Grulee, C. G., Sanford, H. N., and Herron. P. H.: Breast and artificial feeding. Influence on morbidity and mortality of twenty thousand infants. JAMA, 103: 735 (1934).

79. Woodbury, R. M.: The relation between breast and artificial feeding and infant mortality. Am. J. Hyg., 2: 668 (1922).

80. Carpenter, G.: Epidermal growth factor is a major growth-promoting agent in human milk. Science, 210: 198 (1980).

81. Hide, D. W. and Guyer, B. M.: Clinical manifestations of allergy related to breast and cows' milk feeding. Arch. Dis. Child, 56: 172 (1981).

82. Kennell, J. H., Jerauld, R., Wolfe, H., et al.: Maternal behavior one year after early post-partum contact. Develop. Med. Child. Neurol., 16: 172 (1974).

83. Sosa, R., Kennell, J. H., Klaus, M., et al.: The effect of early mother-infant contact on breast feeding infection and growth. In: Breast-feeding and the Mother. Ciba Found, Symp. no 45 (new series). p 179 (Elsevier/Excerpta Medica, Amsterdam, 1976).

84. Jeliffe, D. B. and Jelliffee, E. F. P.: The uniqueness of human milk. Symp. Am. J. Clin. Nutr., 24: 968 (1971).

85. Jelliffe, D. B. and Jelliffe, E. F. P.: "Breast is best": Modern meanings. New Eng. J. Med., 297: 912 (1977).

86. Cameroon, M. and Hofvander, Y.: Manual on Feeding Infants and Young Children (2nd ed), United Nations, N.Y.: Protein-calorie Advisory Group. 1976.

87. Davidson, M., Levine, S. Z., Bauer, C., et al.: Feeding studies in low birth weight infants. I. Relationships of dietary protein, fat, and electrolyte to rates of weight gain, clinical courses and serum chemical concentrations. J. Pediatr., 70: 695 (1967).

88. Synderman, S. E., Boyer, A., Kogut, M. D., et al.: The protein requirement of the premature infant. I. The effect of protein intake on the retention of nitrogen. J. Pediatr., 74: 872 (1969).

89. Kagan, B. M., Stanincova, V., Felix, N. S., et al.: Body composition of premature infants: Relation to nutrition. Amer. J. Clin. Nutr., 25: 1153 (1972).

90. Finberg, L.: Human milk feeding and vitamin D supplementation-1981. J Pediatr. 99: 228 (1981).

91. Greer, F. R., Ho, M., Dodson, D., et al.: Lack of ${ }^{25}$-hydroxyvitamin D and 1,25 dihydroxyvitamin D in human milk. J. Pediatr., 99: 233 (1981).

92. Rowe, J. C., Wood, D. H., Rowe, D. W., et al.: Nutritional hypophosphatemic rickets in a premature infant fed breast milk. New Eng. J. Med., 300: 293 (1979)

93. Raiha, N. C., Heinonen, K., Rassin, D. K., et al.: Milk protein quality in low birthweight infants. I. Metabolic responses and effects on growth. Pediatrics, 57: 659 (1976)

94. Forbes, G. B.: Is human milk the best feed for low birth weight babies? Pediatr. Res. 12: 434 (1978).

95. Atkinson, S. A., Bryan, H., and Anderson, G. H.: Human milk feeding in premature infants: protein, fat, and carbohydrate balances in the first two weeks of life. J. Pediatr. 99: 617 (1981).

96. Hytten, F. E., Yorston, J. C., and Thomson, A. M.: Difficulties associated with breast feeding: a study of 106 primiprarae. Br. Med. J., 1: 310 (1958)

97. Gussler, J. D. and Briesemeister, L. H.: The insufficient milk syndrome: a biocultural explanation. Med. Anthropol., 4: 1 (1980).

98. Waller, H.: The early failure of breast feeding. Arch. Dis. Child., 21: I (1946)

99. Cole, J. P.: Breast feeding in the Boston suburbs in relation to personal-social factors. Clin. Pediatr., 16: 352 (1977).

100. Gilmore, H. E. and Rowland, T. W.: Critical malnutrition in breast-fed infants Amer. J. Dis. Child., 132: 885 (1978).

101. Klein, E. B., Byrne, T., and Cooper, L. Z.: Neonatal rubella in a breast fed infant after postpartum maternal infection. J. Pediatr., 97: 774 (1980).

102. Losonsky, G. A., Fishaut, J. M., Strussenberg, J., et al: Effect of rubella immunization on the products of lactation. II. Maternal-neonatal interactions. J. Infect. Dis. (in press).

103. Beasley, R. P., Stevens, C. E., Shiao, I. S., et al.: Evidence against breast-feeding as a mechanism for vertical transmission of hepatitis B. Lancet 2:740 (1975).

104. Bagnell, P. C. and Ellenberger, H. A.: Obstructive jaundice due to a chlorinated hydrocarbon in breast milk. Can. Med. Assoc. J., 117: 1047 (1977).

105. Bessey, O. A., Adam, D. J. D., and Hensen, A. E.: Intake of vitamin $B_{6}$ and infantile convulsions: a first approximation of requirements of pyridoxine in infants. Pediatrics, 20: 33 (1957).

106. Higginbottom, M. C., Sweetman, L., and Nyan, W. L.: A syndrome of methylmalonic acid uria, homocystinuria, megaloblastic anemia and neurologic abnormalities in vitamin $B_{12}$ deficient breast fed infant of a strict vegetarian. New Eng. J. Med., 299: $31^{3} 7$ (1978).

107. Moran, J. R. and Greene, H. L.: The B vitamins and vitamin C in human nutrition. Amer. J. Dis. Child, 133: 192 (1979).

108. Jackson, R. L., Westerfield, R., Flynn, M. A., et al.: Growth of "well born" American infants fed human and cow's milk. Pediatrics, 33: 642 (1964).

109. Kaplan, M. S. and Solli, N. J.: Immunoglobulin E to cow's milk protein in breast-fed atopic children. J. Allerg. Clin. Immunol., 64: 122 (1979).

110. Juto, P. and Bjorkstein, B.: Serum IgE in infants and influence of type of feeding. Clin. Allerg., 10: 593 (1980).

111. Kenny, J. F. and Zedd, A. J.: Recurrent group B streptococcal disease in and infant associated with the ingestion of infected mother's milk. J. Pediatr., 91: 158 (1977).

112. Schreiner, R. L. Coates, T., and Shackelford, P. G.: Possible breast milk transmission of group B streptococcal infection. J. Pediatr., 91: 159, (1977).

113. The address of Dr. Ogra: Professor of Pediatrics and microbiology, Division of Infectious Diseases, Children's Hospital, 219 Bryant St., Buffalo, NY 14222.

114. The address of Dr. Greene: Professor of Pediatrics and Director of Pediatric Gastroenterology, Vanderbilt University School of Medicine, Nashville, TN 37232.

115. Requests for reprints should be addressed to: Dr. P. Ogra, Professor of Pediatrics and Microbiology, Division of Infectious Diseases, Children's Hospital, 219 Bryant St., Buffalo, NY 14222. 